\title{
Exploitation of the far-offshore wind energy resource by fleets of energy ships. Part B. Cost of energy
}

\author{
Aurélien Babarit ${ }^{1}$, Simon Delvoye ${ }^{1}$, Gaël Clodic $^{1}$, Jean-Christophe Gilloteaux ${ }^{1}$ \\ ${ }^{1}$ LHEEA, Ecole Centrale de Nantes - CNRS, Nantes, 44300, France
}

5 Correspondence to: Aurélien Babarit (aurelien.babarit@ec-nantes.fr)

\begin{abstract}
This paper deals with a new concept for the conversion of far-offshore wind energy into sustainable fuel. It relies on autonomous sailing energy ships and manned support tankers. Energy ships are wind-propelled ships that generate electricity using water turbines attached underneath their hull. Since energy ships are not grid-connected, they include onboard power-to-X plants for storage of the produced energy. In the present work, the energy vector is methanol.

10 In the first part of this study (Babarit et al., submitted), an energy ship design has been proposed and its energy performance has been assessed. In this second part, the aim is to estimate the energy and economic performance of the whole system. Thus, an energy and economic model has been developed which is presented in the paper. Results show that an initial FARWIND system could produce approximately 100,000 tonnes of methanol per annum (approximately $550 \mathrm{GWh}$ per annum of chemical energy) at a cost in the range 150 to $325 € / \mathrm{MWh}$, and that FARWIND-produced methanol could compete

15 with gasoline on the EU transportation fuel market in the long term.
\end{abstract}

\section{Introduction}

To date, fuels such as oil, natural gas and coal account for approximately $80 \%$ of primary energy consumption globally (BP, 2018). Although this share is expected to decrease with the development of renewable power generation and the electrification of the global economy, some sectors may be difficult to electrify (e.g. aviation, freight). Therefore, if a global temperature change of less than $2^{\circ} \mathrm{C}$ - as set out in the Paris agreement-is to be achieved, there is a critical need to develop low-carbon alternatives to fossil fuels.

To address this challenge, we proposed in (Babarit et al., submitted) an energy system (FARWIND) which could convert the far-offshore wind energy resource into sustainable fuel using fleets of energy ships, see Fig. 1. Energy ships are ships propelled by the wind which generate electricity by means of water turbines attached underneath their hulls. The generated electricity is converted into fuel using onboard power-to-gas $(\mathrm{PtG})$ or power-to-liquid (PtL) plants. In the proposed system, the fuel is methanol. It is collected by tankers which are also used to supply the energy ships with the necessary feedstock (carbon dioxide) for power-to-methanol conversion. Of course, the $\mathrm{CO}_{2}$ supply source must be sustainable for that system to produce sustainable methanol. Therefore, the $\mathrm{CO}_{2}$ must be captured either directly or indirectly from the atmosphere. 
Possible options include direct air capture (Keith et al., 2018), $\mathrm{CO}_{2}$ capture from flue gases from biomass or FARWINDproduced methanol combustion, and CO2 from biogas upgrading (Li et al., 2017; Irlam, 2017).

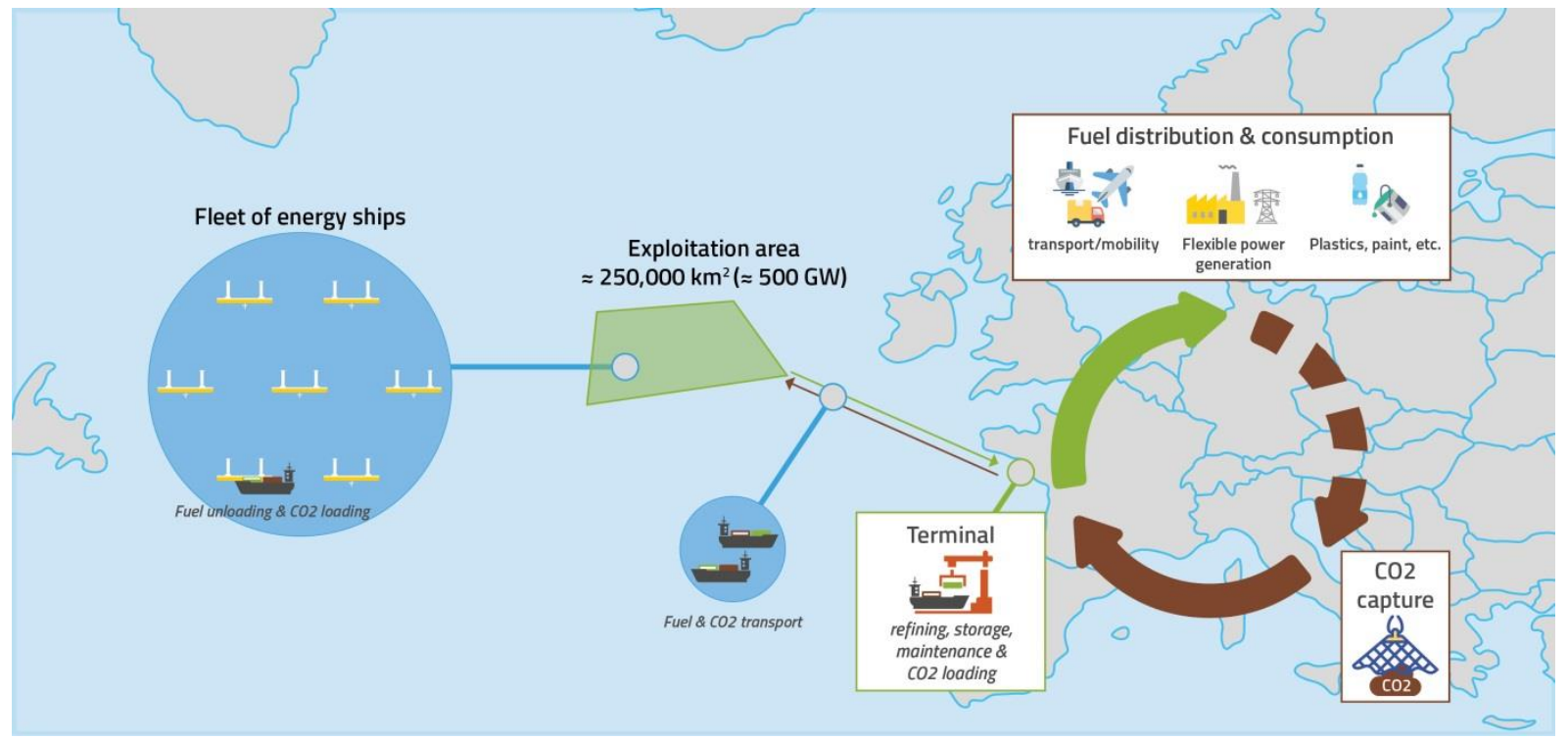

Figure 1 The concept of sustainable methanol production from far-offshore wind energy by FARWIND energy systems.

The overall aim of the present study is to investigate the energy and economic performance of the FARWIND energy system. An energy ship design was proposed in a previous paper (Babarit et al., submitted) and its energy performance was investigated. Elaborating on these results, the aim of the present paper is to estimate the associated cost of energy.

The remaining of this paper is organized as follows. In section 2, the specifications of the proposed energy system are presented and its annual methanol production is estimated. Estimates of expenditures for the proposed energy system are provided and discussed in section 3. Using those estimates and the estimates of annual methanol production, the cost of energy is estimated in section 4 and market perspectives are discussed. Conclusions are presented in Section 5. 


\subsection{Energy ship design}

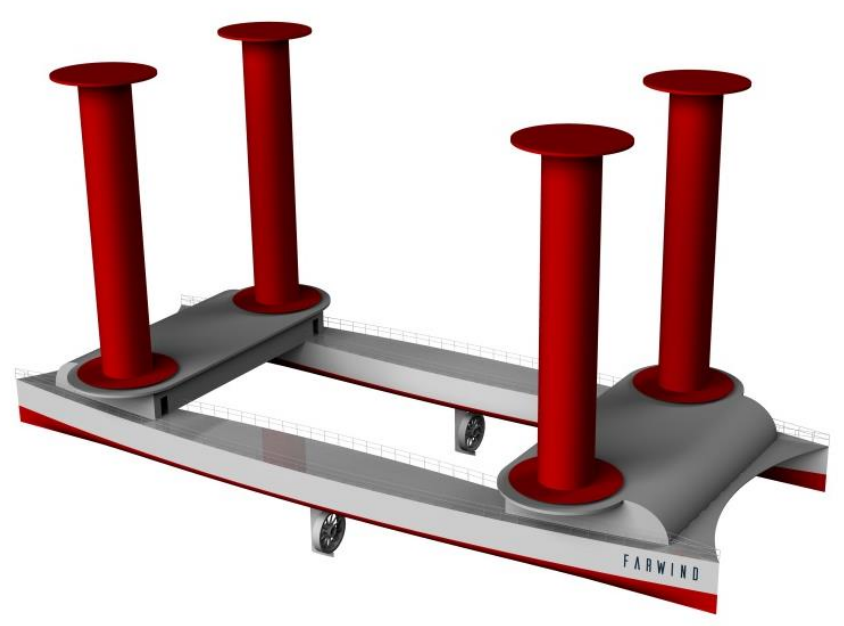

Figure 2 Artist's view of the proposed energy ship design.

The energy ship design considered in this study is that presented in (Babarit et al., submitted). It consists of an $80 \mathrm{~m}$ long catamaran with four $30 \mathrm{~m}$ tall Flettner rotors, and two water turbines, each at rated power $900 \mathrm{~kW}$ each. Fig. 2 shows an artist impression of the proposed design. Its characteristics are recalled in Tab. 1. According to (Babarit et al., submitted), its capacity factor is expected to be $75 \%$ corresponding to an annual methanol production of 905 tonnes.

\begin{tabular}{|c|c|c|}
\hline & Unit & Value \\
\hline Lull & & \\
\hline Bength & $\mathrm{m}$ & 80 \\
\hline Dreadth & $\mathrm{m}$ & 31.7 \\
\hline Displacement & $\mathrm{m}$ & 1.6 \\
\hline Structural mass & $\mathrm{t}$ & 660 \\
\hline Wind propulsion & & 258 \\
\hline Type & - & Flettner rotors \\
\hline Number & - & 4 \\
\hline Rotor height & $\mathrm{m}$ & 30 \\
\hline Rotor diameter & $\mathrm{m}$ & 5 \\
\hline Rotor mass & $\mathrm{t}$ & 59 \\
\hline Rotor rated power & $\mathrm{kW}$ & 110 \\
\hline Water turbine & & \\
\hline Number & - & 4 \\
\hline Turbine diameter & $\mathrm{m}$ & $80 \%$ \\
\hline Rotor-to-electricity efficiency $\left(\eta_{3}\right)$ & - & \\
\hline
\end{tabular}




\begin{tabular}{|c|c|c|}
\hline Turbine mass & $\mathrm{t}$ & 7.4 \\
\hline Rated power & $\mathrm{kW}$ & 900 \\
\hline Auxiliaries subsystems & $\mathrm{kW}$ & 50 \\
\hline Power consumption & $\mathrm{t}$ & 32 \\
\hline Auxiliaries subsystems mass & & 1,420 \\
\hline Power-to-methanol plant & $\mathrm{kW}$ & 35 \\
\hline Electrolyzer rated power & $\mathrm{t}$ & Negligible \\
\hline Electrolyzer mass & $\mathrm{kW}$ & Negligible \\
\hline Desalination unit rated power & $\mathrm{t}$ & 138 \\
\hline Desalination unit mass & $\mathrm{kg} / \mathrm{h}$ & 24 \\
\hline $\mathrm{H}_{2} \mathrm{tMeOH}$ plant capacity & $\mathrm{t}$ & 32 \\
\hline H2tMeOH plant mass & $\mathrm{t}$ & 23 \\
\hline Storage tanks & $\mathrm{t}$ & 23 \\
\hline CO 2 storage capacity & $\mathrm{t}$ & \\
\hline Storage tank mass (empty) & & \\
\hline Methanol storage capacity & & \\
\hline Storage tank mass & & \\
\hline Table 1 Specifications & & \\
\hline
\end{tabular}

Table 1 Specifications of the proposed energy ship design

\subsection{Tanker design}

In the FARWIND concept, the energy ships are deployed in fleets and are supported by tankers which collect the produced methanol and transport it to a shore-based terminal. The tankers also provide the energy ships with $\mathrm{CO}_{2}$.

In the considered energy ship design, the methanol storage tank capacity allows storage of one week of methanol production. Therefore, each and every energy ship of the fleet must meet a tanker for methanol collection and $\mathrm{CO}_{2}$ refill at least once a week (to avoid stops in the production process because the methanol tank is full or because the $\mathrm{CO}_{2}$ tank is empty).

Thus, let us estimate the number of energy ships that can be served by one tanker. This depends on the duration of the $\mathrm{CO}_{2^{-}}$ loading and methanol-unloading operations. We assume that these operations take six hours on average, and that they are carried out continuously (including at night). Therefore, one tanker can service 28 energy ships per week (7 days/week x 24 hours/day / 6 hours/operation). As the capacity of an energy ship's methanol tank is 23 tonnes (32 tonnes for the $\mathrm{CO}_{2} \operatorname{tank}$ ), the tanker may collect up to $644 \mathrm{t}$ of methanol and supply $896 \mathrm{t}$ of $\mathrm{CO}_{2}$ every week.

It is assumed that the tankers are operated by a crew, and that the duration of their mission is four weeks. At the end of each four-week mission, the tanker returns to a shore-based terminal to change crew, unload the methanol and load $\mathrm{CO}_{2}$. 
Therefore, their total methanol capacity must be $2,576 \mathrm{t}$ ( 4 weeks $\times 644 \mathrm{t} /$ week) and their total $\mathrm{CO}_{2}$ capacity must be $3,584 \mathrm{t}$ ( $4 \mathrm{w} \times 896 \mathrm{t} / \mathrm{w}$ ). Assuming the $\mathrm{CO}_{2}$ will be stored as liquid in a cryogenic storage tank, and extrapolating from (Chart, 2019),

65 the empty weight of a 3,584 t capacity $\mathrm{CO}_{2}$ storage vessel is estimated to be 2,240 t. For methanol, the mass of the required tank is estimated to be $518 \mathrm{t}$. The tanker will be carrying maximum cargo weight $(6,342 \mathrm{t})$ when it leaves the terminal (full $\mathrm{CO}_{2}$ tank and empty methanol tank). This cargo weight is relatively similar to the average vessel size of small crude oil (3,600 deadweight (dwt)), chemical (4,900 dwt) and LPG vessels (3,500 dwt) (Lindstad et al., 2012). According to (MAN Energy Solutions, 2019), the propulsion power of a 5,000 t deadweight bulk carrier is 1,410 kW for a service speed of 12 knots. These are the values used for the service speed and propulsion power of the tanker.

\subsection{FARWIND system design and annual methanol production}

Following (Babarit et al., 2018), it is assumed that the fleet of energy ships is deployed at a distance of 1,000 km from the terminal. Therefore, the tankers have to travel $1,000 \mathrm{~km}$ to meet the energy ships, and a further $1,000 \mathrm{~km}$ when returning to the terminal. At a service speed of 12 knots, the tanker's round-trip will take 90 hours. Taking into account the duration of unloading/loading operations and other maintenance operations, we estimate that the tanker will be away from the fleet of energy ships for a duration of one week.

To ensure continuous operation of the energy ships, the tanker must be replaced immediately when it leaves the production zone. Therefore, each group of 28 energy ships must be supported by more than one tanker. It can be shown that the minimum number of tankers per fleet must be at least 1.25, meaning that the optimal FARWIND system comprises a fleet of

80112 energy ships supported by five tankers. Over a year, the number of round-trips between the terminal and the production zone is 10.4 for each tanker. The maximum methanol production of that system (assuming $100 \%$ capacity factor for the energy ships) is approximately $135,000 \mathrm{t}$ per annum. Assuming an average capacity factor of $75 \%$, the annual methanol production would be approximately $100,000 \mathrm{t}$ per annum. Note that it would require the supply of approximately $140,000 \mathrm{t}$ of $\mathrm{CO}_{2}$.

\section{Estimation of expenditures}

\subsection{Capital cost of a first of a kind energy ship}

\begin{tabular}{|c|c|}
\hline & Cost (k€) \\
\hline Energy ship & \\
\hline Hull & $1,290-5,160 \mathrm{k} €$ \\
\hline Flettner rotors & $3,000-3,500 \mathrm{k} €$ \\
\hline Water turbine & $488 \mathrm{k} €$ \\
\hline Electrolyzer & $1,280-1,700 \mathrm{k} €$ \\
\hline $\mathrm{H}_{2}$-to-methanol plant & $1,030-1,380 \mathrm{k} €$ \\
\hline
\end{tabular}




\begin{tabular}{|c|c|}
\hline Fresh water production unit & $11 \mathrm{k} €$ \\
\hline Liquid $\mathrm{CO}_{2}$ tank & $32 \mathrm{k} €$ \\
\hline Methanol tank & $7 \mathrm{k} €$ \\
\hline $\begin{array}{c}\text { Auxiliaries, assembly and } \\
\text { systems integration }\end{array}$ & $1,430-2,450 \mathrm{k} €$ \\
\hline Total & $\mathbf{8 , 5 7 0}-\mathbf{1 4 , 7 0 0} \mathbf{k} €$ \\
\hline
\end{tabular}

Table 2 Estimates of the capital cost of a prototype of the proposed energy ship

Tab. 2 shows estimates of the capital cost of a prototype of the proposed energy ship. The water turbine cost and the fresh water production unit cost were estimated using scaling laws which were developed by Holl et al. (Holl et al., 2016) based on market surveys. They are dependent on the nominal power of the equipment. They yielded cost estimates of $244 \mathrm{k} €$ per water turbine, and only $11 \mathrm{k} €$ for fresh water production, which is very small in comparison to the other costs.

Holl et al. also provide scaling laws for the cost of the electrolyzer and the vessel, based on the nominal power of the electrolyzer and the vessel length, respectively. Applying the scaling law to the $1,420 \mathrm{~kW}$ capacity electrolyzer of the energy ship results in an estimated cost of $1,845 \mathrm{k} €$, equivalent to $1,300 € / \mathrm{kW}$. This is greater than the 1,000 to $1,200 € / \mathrm{kW}$ reported in (Gotz et al., 2016) and (Chardonnet et al., 2017) for alkaline electrolyzers (AEL). It is possible that Holl et al. may have considered PEM electrolyzers, which are more expensive (Gotz et al., 2016). Moreover, according to (Chardonnet et al., 2017), the cost of AEL electrolyzers is expected to decrease to $900 € / \mathrm{kW}$ by 2025 . Therefore, we used the range 900 to 1,200 $€ / \mathrm{kW}$ to estimate the electrolyzer cost, yielding a final cost of 1,280 to $1,700 \mathrm{k} €$.

The scaling law that Holl et al. developed for vessel cost was based on data for sailing ships of length 10-20 m. Extrapolating from this data, an $80 \mathrm{~m}$ long vessel would cost in the order of $11 \mathrm{M} €$, equivalent to a specific cost of 42,000€ per tonne of structural mass, which is very high. In contrast, data from (Lindstad et al., 2012) and (Papanikolaou, 2014) suggest that the price of commercial ships is in the range 3,000 to $16,000 €$ per tonne of structural mass (steel), depending on the type and size of ship. However, lightweight materials such as aluminium or glass fibre reinforced polymers (GFRP) may be required to achieve sufficient structural strength in the structural mass budget of the energy ship. The greater cost of those materials (approx. $1 € / \mathrm{kg}$ for steel, $3 € / \mathrm{kg}$ for aluminium, $6 € / \mathrm{kg}$ for GFRP) would increase the specific cost to 5,000 $€$ per tonne for aluminium or $8,000 €$ per tonne for GFRP. As the hull material is unknown at this stage, we retain a cost range of 5,000 to $20,000 €$ per tonne, corresponding to a hull cost in the range 1,290 to $5,160 \mathrm{k} €$.

According to (Kuuskoski, 2019), the cost of four Flettner rotors is in the range 3,000 to 3,500 $\mathrm{k} €$.

According to (Anicic et al., 2014), the cost of a power-to-methanol plant is approximately $81 \%$ of the cost of the electrolyzer, yielding a cost of 1,030-1,380 k€ for the energy ship's hydrogen-to-methanol plant. For the liquid $\mathrm{CO}_{2}$ and methanol storage tanks, suppliers and prices can be found on the internet (e.g. https://www.gitank.com/methanol-storage$\underline{\text { tanks, }}$ (Chart, 2019)); typical costs are $300 € /$ tonne of capacity for methanol and 1,000 €/tonne of capacity for liquid $\mathrm{CO}_{2}$. 
Finally, ship common systems, ship assembly and systems integration represent $20 \%$ of the total cost according to (Shetelig, 2013). Applying this ratio to the energy ship leads to an estimated total capital cost of approximately 8,570 to $14,700 \mathrm{k} €$ for

115 a first of a kind energy ship.

\subsection{Capital cost of a first of a kind FARWIND energy system}

According to the discussion in section 2.3, a FARWIND energy system should include a fleet of 112 energy ships and 5 tankers. One can expect the unit cost for a fleet of 112 energy ships to be significantly smaller than the cost of an energy ship protoype. To take this into account, a learning rate of $10 \%$ was assumed on the unit cost of the energy ship as function of the built capacity, see Tab. 2. It can be noted that such learning rate corresponds to what was observed for wind turbines (Lindman and Soderholm, 2012). It leads to a range of capital cost of 545 to $938 \mathrm{M} €$ for the first fleet of energy ships. It corresponds to an average unit cost of 4,550 to 7,830 k€ per energy ship.

For the tanker, according to (Lindstad et al., 2012), the price of commercial ships is in the range $500 €$ to $4,750 €$ per tonne of dwt, depending on the type of ships and size. The lower price is for crude oil tankers with greater than 140,000 dwt, while the higher price is for roll-in/roll-off (ro-ro) ships of 7,000 dwt. In the present study, we retain a cost range of 2,500 to 4,000 $€ /$ tonne of deadweight, leading to a tanker cost in the range 15,800 to $25,300 \mathrm{k} €$.

Thus, overall, the total capital cost of a FARWIND system comprised of 112 energy ships and 5 tankers is expected to be in the range of 625 to $1,065 \mathrm{M} €$, for an approximately $200 \mathrm{MW}$ capacity. For the sake of comparison, the capital cost of the 498 MW bottom-fixed offshore wind farm near Fécamp (France) is approximately 2 billion euros. Therefore, the capital costs per installed megawatt are comparable (3,125 to 5,325 k€/MW for the FARWIND system vs 4,000 M€/MW for the Fécamp wind farm).

\subsection{Operational expenditures}

Expected operation and maintenance (O\&M) costs, including the cost of $\mathrm{CO}_{2}$ supply, are summarized in Tab. 3 and detailed below.

\begin{tabular}{|c|c|}
\hline & $\begin{array}{c}\text { O\&M cost (in \% of capital } \\
\text { cost of equipment per year) }\end{array}$ \\
\hline Energy ship & \\
\hline Hull & $1-2 \%$ \\
\hline Flettner rotors & $7 \%$ \\
\hline Water turbine & $4-13 \%$ \\
\hline Auxiliaries & $7 \%$ \\
\hline Electrolyzer & $4 \%$ \\
\hline $\mathrm{H}_{2}$-to-methanol plant & $4 \%$ \\
\hline Fresh water production unit & $10-20 \%$ \\
\hline
\end{tabular}




\begin{tabular}{|c|c|}
\hline Liquid $\mathrm{CO}_{2}$ tank & $1-2 \%$ \\
\hline Methanol tank & $1-2 \%$ \\
\hline Total & $\mathbf{4 . 8}-\mathbf{5 . 1 \%}$ \\
\hline Tanker & $4-10 \%$ \\
\hline FARWIND system & $28-45 \mathrm{M} € / \mathrm{y}$ \\
\hline Energy ships maintenance & $3.2-13 \mathrm{M} € / \mathrm{y}$ \\
\hline Tankers O\&M & $2.8-28 \mathrm{M} € / \mathrm{y}$ \\
\hline $\mathrm{CO}_{2}$ supply & $\mathbf{5 . 4}-\mathbf{8 . 1 \%}$ \\
\hline Total (including $\mathbf{C O}_{2}$ supply) &
\end{tabular}

Table 3 Estimates of the operation and maintenance costs of the optimal FARWIND system

\subsubsection{Energy ships and tankers operation and maintenance cost}

According to (Holl et al., 2016), the maintenance cost of the water turbine is in the range 4 to $13 \%$ of the capital cost, and that of the fresh water production unit is between 10 and 20\%. According to (Chardonnet et al., 2017), the maintenance cost for the electrolyzer is in the order of $4 \%$ of capital cost. The same ratio is assumed for the hydrogen to methanol plant.

For the Flettner rotors and the auxiliaries, it is assumed that the maintenance cost is similar to that of offshore wind turbines, which is 7\% of capital cost according to (Moné et al., 2015). For the other subsystems (hull, storage tanks), it is expected that the maintenance costs would be small; a range of 1 to $2 \%$ maintenance cost was arbitrarily selected. Overall maintenance costs for the energy ship are thus in the order of $5 \%$.

145 For the tanker, following (Holl et al., 2016), we estimate operation and maintenance costs to be 4 to $10 \%$.

\subsection{2 $\mathrm{CO}_{2}$ supply cost}

The ambition of the FARWIND energy system is to provide a sustainable alternative to the use of liquid fossil fuels (e.g. oil). Therefore, as mentioned in the introduction, the $\mathrm{CO}_{2}$ must be captured directly or indirectly from the atmosphere.

According to (Keith et al., 2018), the cost for direct air capture (DAC) using large-scale wet absorption DAC technology is

150 in the range 80 to $204 € /$ tonne of $\mathrm{CO}_{2}$. The cost of $\mathrm{CO}_{2}$ capture from biogas upgrading is in the order of 15 to $100 € /$ tonne of $\mathrm{CO}_{2}$ ( $\mathrm{Li}$ et al., 2017). In the case of $\mathrm{CO}_{2}$ capture from flue gases from combustion of biomass or FARWIND-produced methanol, the cost of carbon capture is in the order of 35 to $50 € /$ tonne (assuming that it would be similar to that for capture of $\mathrm{CO}_{2}$ from power production processes involving coal or natural gas (Irlam, 2017)). Note that for both biogas upgrading and biomass or methanol combustion, the $\mathrm{CO}_{2}$ concentration in the source is much greater than in ambient air, which results

155 in a more effective capture than with DAC.

Carbon dioxide may also be extracted from seawater (Willauer et al., 2012). Indeed, some of the $\mathrm{CO}_{2}$ present in the atmosphere dissolves in the ocean. However, this new technology is in its early stages of development (Willauer et al., 2017). 
https://doi.org/10.5194/wes-2019-101

Preprint. Discussion started: 24 February 2020

(c) Author(s) 2020. CC BY 4.0 License.

(c) (i)

In any case, the captured $\mathrm{CO}_{2}$ must be liquefied for efficient transportation. The energy requirement for $\mathrm{CO}_{2}$ liquefaction is in the order of $0.1 \mathrm{kWh} / \mathrm{kg}_{\mathrm{CO} 2}$ according to (Oi et al., 2016), which is low; hence its associated cost is expected to be negligible.

Therefore, we estimate the cost of $\mathrm{CO}_{2}$ production to be in the range 20 to $200 € /$ tonne. As approximately $140,000 \mathrm{t}$ of $\mathrm{CO}_{2}$ are required to produce $100,000 \mathrm{t}$ of methanol, the $\mathrm{CO}_{2}$ supply cost is estimated to be in the range 2,800-28,000 $\mathrm{k} €$ per annum.

\section{Cost of energy estimates}

\subsection{Short-term cost}

The levelized cost of methanol LCOM can be calculated as (Holl et al., 2016):

$$
L C O M=\frac{C R F+\lambda}{A M P} I
$$

where $I$ is the total capital cost, $\lambda$ is the total O\&M rate, $A M P$ is the annual methanol production, and $C R F=\frac{i(1+i)^{n}}{\left((1+i)^{n}-1\right)}$ is the capital recovery factor, in which $i$ is the interest rate on capital and $n$ is the lifetime in years.

Assuming an interest rate in the range $6-10 \%$ and a lifetime of 20 years, the capital recovery factor is in the range 8.7$11.7 \%$. The methanol cost is thus in the range $0.87-2.08 € / \mathrm{kg}$ (157 to $376 € / \mathrm{MWh}_{\mathrm{th}}$ ).

This cost is two to five times greater than current market price for methanol (360€/t $\approx 65 € / \mathrm{MWh}$ in the first quarter of 2019). However, it does not take into account a price on GHG emissions. At least $0.675 \mathrm{~kg}$ of $\mathrm{CO}_{2}$ is produced per $\mathrm{kg}$ of

175 methanol produced using conventional processes (which are based on coal or natural gas) (Martin and Grossmann, 2017). In 2018, the carbon tax was $44.6 € /$ tonne in France and $110 € /$ tonne in Sweden; if $\mathrm{CO}_{2}$ emissions were taken into account in these countries, the methanol price would increase by $6 € / \mathrm{MWh}_{\mathrm{th}}$ and $13 € / \mathrm{MWh}_{\mathrm{th}}$ respectively. Thus, unfortunately, even with a rather significant carbon tax, the cost of FARWIND-produced methanol would not be competitive in the short term. 


\subsection{Long-term cost}

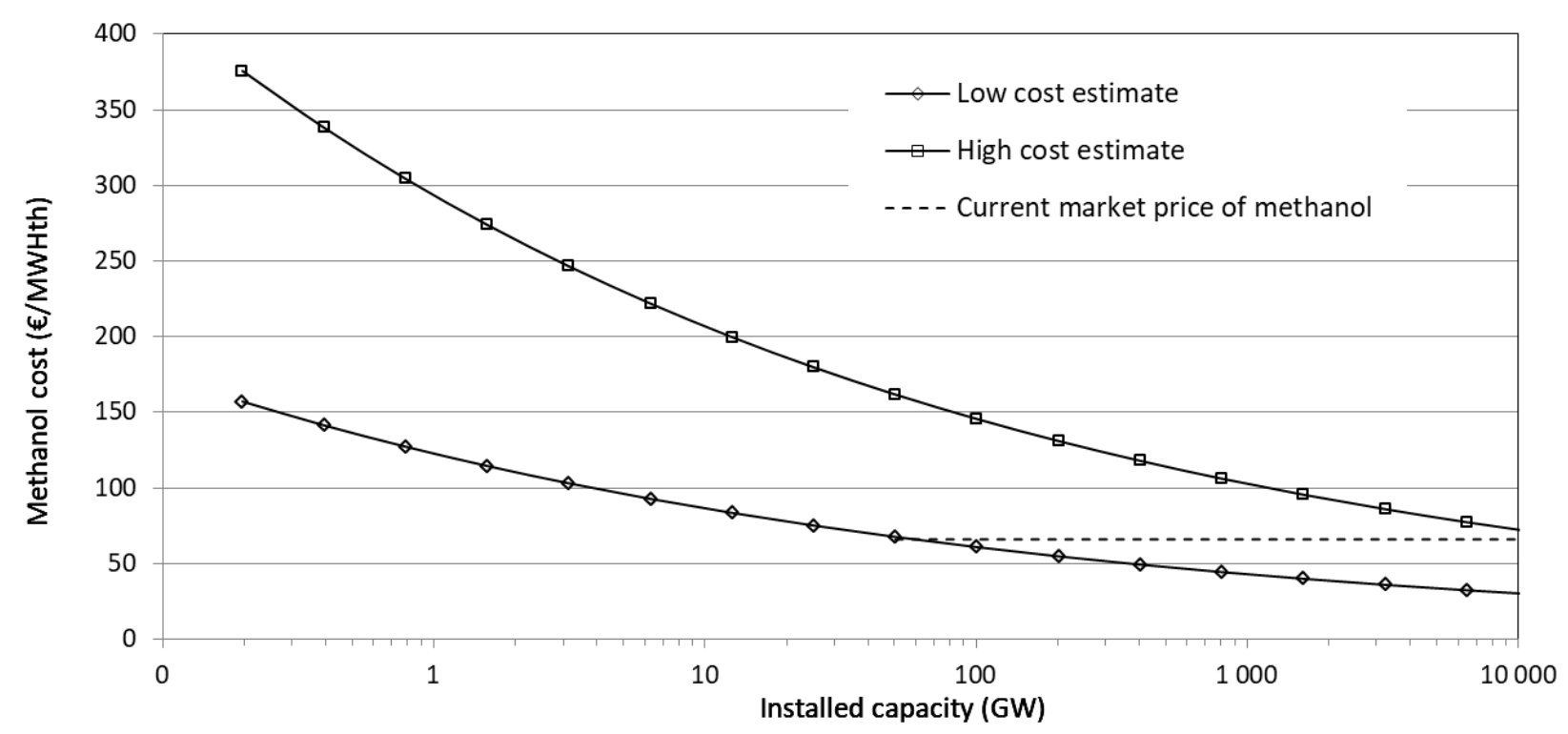

180

Figure 3 Cost of methanol produced by FARWIND systems as function of the installed capacity and comparison with the current market price of methanol produced from fossil fuels and feedstocks

However, as for the energy ships, one can expect that the cost of FARWIND systems will decrease with increasing installed capacity. Fig. 3 shows the expected cost reduction for the methanol cost as function of the installed capacity. A learning rate

of $10 \%$ was assumed (as for the energy ships, see section 3.2). One can see that it would take hundreds to thousands of GW of installed capacity to achieve competitiveness with methanol produced from fossil fuels.

\subsection{Market potential}

Finally, let us consider the perspective of FARWIND-produced fuel for the transportation fuel market. Indeed, methanol can be blended with gasoline in low quantities for use in existing road vehicles. According to (Methanol Institute, 2014), the blend can include up to $15 \%$ methanol by volume (M15 fuel). Moreover, flexible fuel vehicles which can run on an $85 \%-$ 15\% methanol-gasoline mix (M85 fuel) have been developed and commercialized (e.g. the 1996 Ford Taurus); and M100 (100\% methanol) vehicles are in development (Olah et al., 2018). Thus, FARWIND-produced methanol could be used as a low-carbon substitute to oil on the transportation fuel market. 


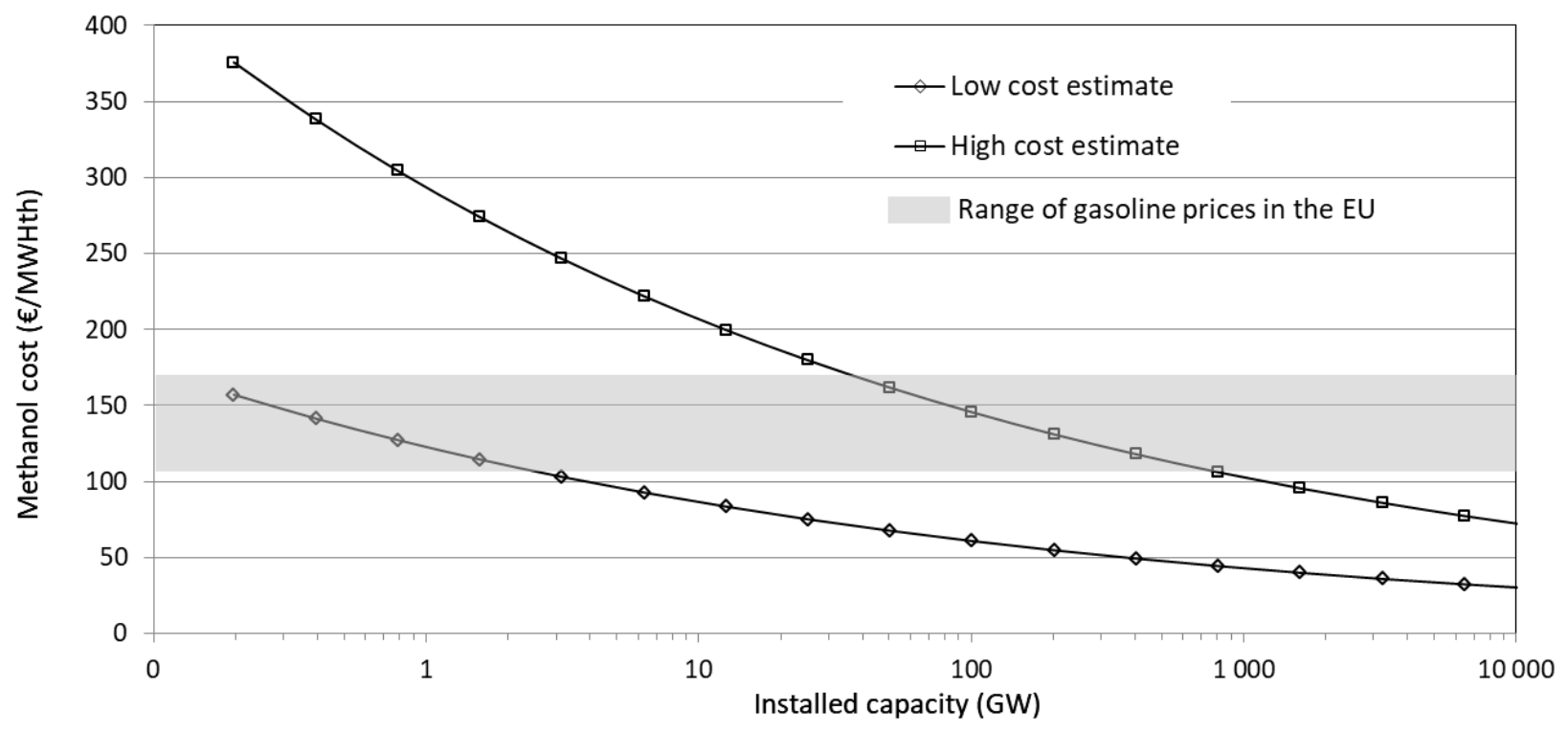

Figure 4 Cost of methanol produced by FARWIND systems as function of the installed capacity and comparison with current market price of gasoline in the $\mathrm{EU}$

Let us compare the cost of FARWIND-produced methanol to the gasoline price in the EU. Gasoline price ranges from 1.1 $€ / \mathrm{L}$ (Bulgaria) to $1.7 € / \mathrm{L}$ (Netherlands), the price differences arising from different policies on fuel taxes in different countries (European Commission, 2019). This price range is equivalent to 112 to $173 € / \mathrm{MWh}_{\mathrm{th}}$, since the standard density of gasoline traded in the EU is $0.755 \mathrm{~kg} / \mathrm{L}$ and its energy content is approximately $13 \mathrm{kWh}_{\mathrm{th}} / \mathrm{kg}$. Thus, as can be seen in Fig. 4 and provided that taxes policies are favourable to FARWIND-produced methanol, it could take "only" a few GW to a few tens of GW of installed capacity to be competitive with gasoline on the EU transportation fuel market.

\section{Conclusions}

In this paper, we presented a concept for sustainable methanol production from the far-offshore wind energy resource. It is based on autonomous fleets of energy ships for the fuel production and manned tankers for the collection and transport of the produced methanol, as well as the supply of $\mathrm{CO}_{2}$ to the energy ships

The proposed FARWIND energy system includes a fleet of 112 energy ships supported by five dedicated tankers. Its methanol production is expected to be in the order of 100,000 $\mathrm{t}$ per annum (approximately $550 \mathrm{GWh}$ per annum of chemical energy). The cost of this methanol is expected to be in the range $0.87-2.08 € / \mathrm{kg}$ for the first-of-a-kind FARWIND system, which is significantly greater than the current market price for fossil fuel-derived methanol $(0.36 € / \mathrm{kg})$. However, methanol can be used as a substitute to fossil fuels on the fuel transportation market: since the price of transportation fuel is high in most European countries, and assuming that a cost reduction similar to that observed for land-based wind energy can be achieved, the cost of FARWIND-produced methanol could compete with gasoline in the EU. 
Nevertheless, it must be acknowledged that the FARWIND system is only in the early stages of development. Future work is

required to confirm the potential: challenges include the development and validation of the key subsystems (water turbine, autonomous power-to-methanol plant, control systems for autonomous navigation) and addressing the possible non-technical barriers to far-offshore wind energy (legal status of autonomous far-offshore wind energy converters, environmental impacts).

\section{Acknowledgements}

220 This research was partially supported by the French National Energy and Environmental Agency (ADEME) and Région Pays de la Loire.

\section{References}

Anicic, B., Trop, P., Goricanec, D.: Comparison between two methods of methanol production. Energy, 77, 279-289, 2014

BP: BP Statistical review of world energy, $67^{\text {th }}$ edition, June 2018

225 Babarit, A., Gilloteaux, J-C., Clodic, G., Duchet, M., Simoneau, A., Platzer, M.F. : Techno-economic feasibility of fleets of far offshore hydrogen-producing wind energy converters. International Journal of Hydrogen Energy, 43(15), 7266-7289, 2018

Babarit, A., Gilloteaux, J-C.: Sustainable methanol production from the far-offshore wind energy resource by fleets of energy ships. Part I. Energy ship design and performance, Submitted

230 Chardonnet, C., De Vos, L., Genoese, F., Roig, G., Giordano, V., Rapoport, S., et al. : Study on early business cases for H2 in energy storage and more broadly power to H2 applications. Tractebel \& Hinicio. Final report, 2017

Chart, Technical manual: carbon dioxide storage tank. Manual \#11650869 Rev, 2019

European Commission: Consumer prices of petroluem products inclusive of duties and taxes. Prices in force on 18/11/2019, 2019

235 Holl, M., Rausch, L., Pelz, P.F.: New methods for new systems - how to find techno-economically optimal hydrogen conversion system. International Journal of Hydrogen Energy, 42, 22641-22654, 2017

Gotz, M., Lefebvre, J., Mors, F., McDaniel Koch, A., Garf, F., Bajohr, S., Reimert, R., Kolb, T.: Renewable power-to-gas: a technological and economic review, Renewable Energy, 85, 1371-1390, 2016

Keith, D.W., Holmes G., St Angelo, D., Heidel, K.: A process for capturing CO2 from the atmosphere, Joule, 2, 1573-1594, 2402018,2018

Irlam, L., Global costs of carbon capture and storage - 2017 update. Global CCS institute, June 2017

Li, H., Tan, Y., Ditaranto, M., Yan, J., Yu, Z.: Capturing CO2 from biogas plants, Energy procedia, 114, 6030-6035, 2017

Lindman, A., Soderholm, P.: Wind power learning rates: a conceptual review and meta-analysis, Energy economics, 34, 754-

761,2012 
https://doi.org/10.5194/wes-2019-101

Preprint. Discussion started: 24 February 2020

(c) Author(s) 2020. CC BY 4.0 License.

(c) (1)

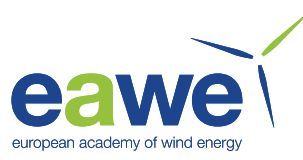

245 Lindstad, H., Asbjornslett, B.E., Stromman, A.H.: The importance of economies of scale for reductions in greenhouse gas emissions from shipping. Energy policy, 46, 386-398, 2012

Kuuskoski, J.: Private communication, 2019

MAN Energy solutions: propulsion trends in bulk carriers, 2019

Martin, M., Grossmann, I.E.: Towards zero $\mathrm{CO} 2$ emissions in the production of methanol from switchgrass. $\mathrm{CO} 2$ to 250 methanol. Computers and chemical engineering, 105, 308-316, 2017

Methanol Institute , M15 methanol gasoline blends: 35 years of research and experience supports its use. Methanol facts, 2014

Moné, C., Stehly, T., Maples, B., Settle, E.: 2014 cost of wind energy review. Technical report NREL/TP-6A20-64281, National Renewable Energy Laboratory, Golden, CO, 2015

255 Oi, L.E., Eldrup, N., Adhikari, U., Bentsen, M.H., Badalge, L., Yang, S.: Simulation and cost comparison of CO2 liquefaction, Energy procedia, 86, 500-510, 2016

Olah, G.A., Goeppert, A., Surya Prakash, G.K.: Beyond Oil and Gas: the methanol economy. Third, updated and enlarged edition. Wiley-VCH, 2018

Papanikolaou, A.: Chapter 2: Selection of main dimensions and calculation of basic ship design value. In: Ship Design: 260 methodologies of preliminary design. Springer 628 pp., 2014

Shetelig, K.: Shipbuilding cost estimation: parametric approach. Norwegian University of Science and Technology, Trondheim, Norway. 61 pp, 2013

Willauer, H.D., Hardy, D.R., Schultz, K.R., Williams, F.W.: The feasibility and current estimated capital costs of producing jet fuel at sea using carbon dioxide and hydrogen. Journal of Renewable and sustainable energy, 4, 2012

265 Willauer, H.D., DiMascio, F., Hardy, D.R.: Extraction of carbon dioxide and hydrogen from seawater by an electrolytic cation exchange module (E-CEM) part V: E-CEM effluent discharge composition as a function of electrode water composition. Washington D.C.:Naval research laboratory, 2017 